\title{
BIOGRAFIA JĘZYKOWA JAKO PRZYCZYNEK DO REFLEKSJI NAD MOTYWACJĄ DO NAUKI JĘZYKA NIEMIECKIEGO
}

\author{
Language biography - Considerations on the motivation \\ of German language learning
}

\begin{abstract}
A language biography is most often a reflection on one's own linguistic development and therefore can be termed "language autobiography". In its a broad sense, a language biography may include mother tongue acquisition, yet this article focuses solely on foreign language learning, with a special emphasis on the German language. The article provides insights into factors that motivate learners of German and into changes in these factors over a period of time, including the role of intercultural motivators. A theoretical and methodological introduction is followed by the results of a qualitative study conducted in five Polish institutions of tertiary education on a group of 73 students learning German. The excerpts of biographies quoted provide a picture of motivation as a dynamic process and moreover indicate that as present-day students get older, they are increasingly more thoughtful about their learning.
\end{abstract}

Keywords: German as foreign language, history of German teaching, German teaching in Poland, Polish-German cultural relations

Słowa kluczowe: niemiecki jako język obcy, historia nauczania języka niemieckiego, nauczanie języka niemieckiego w Polsce, polsko-niemieckie relacje kulturowe

\section{Wprowadzenie}

Motywy stanowią fundament motywacji w procesie uczenia się języków obcych. W badaniu motywacji uwzględnia się poza identyfikacją motywów także 
inne czynniki, takie jak intensywność wysiłków, czy różne nastawienia wobec języka obcego i kontekstu edukacyjnego. Wg Edmonsona (1997: 89) motywację można rozumieć jako gotowość poświęcania czasu, energii oraz innych osobistych zasobów w celu osiągnięcia określonego celu, w tym przypadku opanowania języka obcego. Gardner (1985: 10) ujmuje z kolei motywację jako kombinację wysiłków (intensywność motywacyjna), pragnienia osiągnięcia celu i pozytywnych nastawień do nauki języka obcego. Jednocześnie w rozważaniach teoretycznych coraz mocniej podkreśla się dynamiczny i procesowy charakter motywacji (por. Dörnyei i Ottó, 1998; Pawlak, 2012). W określaniu stopnia dynamiki motywacji szczególnie efektywne są badania longitudinalne (podłużne). W przypadku badań poprzecznych, ilościowych czy jakościowych, to refleksyjność uczących się języka obcego może stanowić podstawę do pozyskania danych na temat procesów motywacyjnych w ujęciu retrospektywnym.

Niniejszy artykuł poświęcony jest motywacji polskich studentów do nauki języka niemieckiego w świetle sporządzanych na potrzeby badania jakościowego biografii językowych. Refleksje osób badanych stanowią przyczynek do analizy motywacji, jej wewnętrznego i zewnętrznego charakteru oraz zmian w perspektywie długoterminowej. Biografie językowe pozwoliły, dzięki odpowiedniej strukturze formularza, uwzględnić znaczenie nie tylko motywacji instrumentalnej, ale także ewentualnej motywacji interkulturowej. Koncepcja motywacji interkulturowej wyrasta po części z propozycji Gardnera i Lamberta (1972) oraz Gardnera (1985) i modelu socjopedagogicznego przewidującego m.in. tzw. „orientację integracyjną” uczących się języka obcego. Dla naszej koncepcji ważne było jednak także uwzględnienie innych aspektów socjokulturowych uczenia się języków obcych, przede wszystkim tych związanych z postulatami podejścia interkulturowego w dydaktyce języków obcych. Za szczególnie istotny uznano przy tym postulat kształtowania kompetencji interkulturowej. Motywy interkulturowe mogą mieć więc charakter kognitywny, afektywny lub konatywny i nawiązywać do jednego z trzech głównych zakresów kompetencji interkulturowej: wiedzy, postaw i nastawień oraz umiejętności. Biografie językowe wydają się być odpowiednim narzędziem dla wychwycenia takich motywów lub stwierdzenia ich braku.

\section{Biografia językowa jako instrument badań jakościowych}

Biografia językowa (autobiografia) jako narzędzie badań empirycznych w glottodydaktyce pozwala uchwycić te aspekty akwizycji języka obcego, które mogą podlegać zmianom w dłuższej perspektywie. Oprócz dokumentowania rozwoju poszczególnych sprawności językowych, sporządzane przez 
uczących się języka obcego biografie rejestrują np. zmiany w sferze świadomości językowej (language awarenes), świadomości kulturowej (culture awareness), ilustrują ewentualne zmiany w nastawieniu do języka i jego uczenia się, czy stopień satysfakcji (samoocenę) w różnych fazach procesu uczenia się języka. Dla niniejszych rozważań nie bez znaczenia jest fakt, iż biografia językowa, rozumiana jako instrument badania jakościowego, pozwala także uchwycić procesowy, dynamiczny charakter motywacji.

Pojęcie „biografii językowej” obejmuje w istocie różne, związane ze sobą koncepcje dotyczące zarówno akwizycji języka pierwszego, jak i języka drugiego czy języka obcego. Dla naszych badań istotne jest spostrzeżenie, iż konstrukcja biografii językowej w pamięci jest warunkiem dla opisu biograficznego (Tophinke, 2002: 7). Biografie językowe są nade wszystko refleksją nad „przeżyciem sfery językowej” (Franceschini, 2002: 20) i można je określić jako „językowe autobiografie" (ibidem). Rekonstrukcja biografii językowej nie jest powiązana z żadną specyficzną formą tekstu, tak więc może ona stanowić zarówno dłuższy tekst narracyjny na temat własnej historii akwizycji języka lub jego uczenia się, jak też krótsze sekwencje tekstowe, które są formułowane pisemnie lub ustnie (Tophinke, 2002: 8). W tym ostatnim przypadku wypowiedzi mogą się koncentrować na stosunku i nastawieniu do języka, opanowaniu języka mówionego i pisanego, kompetencjach językowych, itp. (ibidem). W niniejszym badaniu pozyskiwano właśnie takie krótsze wypowiedzi, które skupiały się na określonych, przede wszystkim motywacyjnych aspektach uczenia się języka niemieckiego, oraz na postrzeganiu kultury języka docelowego.

Biografie językowe, które wykorzystywane są w sposób nieco ograniczony i służą do gromadzenia danych odnoszących się do uczenia się języka obcego (wraz z wątkiem motywacyjnym) określa się także „biografiami motywacji w nauce języka" (Sprachlernmotivationsbiographien - por. Riemer, 2003: 79). W. J. Edmondson, który badał m.in. świadomość językową i motywację wśród uczących się języka angielskiego, nazywa swój instrument badań jakościowych „autobiografią uczenia się języka obcego” (Fremdsprachenlernautobiographie - por. Edmondson, 1997: 92). C. Riemer, bardzo zasłużona na niemieckim polu badań motywacji i nadająca kierunek kolejnym studiom empirycznym (m.in. poprzez szczegółowe wskazówki metodologiczne, por. Riemer, 2010), wykorzystała w szeregu swoich badań (Riemer, 2003; 2004; 2005; 2006) format ankietowy oparty na propozycjach Edmondsona (1996; 1997; 2000) i odpowiednio zmodyfikowany. Biografie, które skupiały się na akwizycji zarówno języka angielskiego, jak i niemieckiego, sporządzane były pisemnie 
i miały formę otwartą. Badani otrzymywali jedynie impuls ${ }^{1}$, który wprawdzie kładł nacisk na istotne dla badacza aspekty i werbalizował jego oczekiwania, jednakże taka forma pozostawiała nadal duże pole manewru.

Riemer (2004: 55) w swoich rozważaniach metodologicznych wskazuje na ryzyko, iż poprzez zbyt otwarte formy badań otrzymuje się zbyt mało wymowne dane, a poprzez podkreślanie różnych aspektów dane te są trudno porównywalne. Także jakość pozyskanych danych nie może być zagwarantowana przez wykorzystanie instrumentu pisemnej biografii (ibidem). Przewidywalne słabości tego formatu leżą paradoksalnie w jego dużej otwartości, która dopiero wtedy przyczynia się do wysokiej jakości wyników, jeżeli jest przez badanych traktowana poważnie i prowadzi do głębszych refleksji, a nie tylko do powierzchownych i nieprzemyślanych odpowiedzi. Jednocześnie ta otwartość w badaniach jakościowych musi być rozumiana jako otwartość „naukowo obudowana i kontrolowana" (Fuhs, 2007: 49). Przy możliwie największej otwartości na „nowe i nieoczekiwane”, proces badawczy musi być ciągle strukturyzowany, zrozumiały i zorientowany na pytania badawcze (por. ibidem). Proponowany tutaj format biografii językowej kieruje się tą zasadą.

\section{Opis badania}

Badanie motywów i motywacji uczących się języka niemieckiego z uwzględnieniem refleksji badanych nad całym okresem, począwszy od decyzji podjęcia nauki po aktualny lektorat na uczelni, miało na celu prześledzenie zarówno możliwych zmian w samej motywacji, jak i sprawdzenie poziomu refleksyjności studentów w odniesieniu do poszczególnych etapów nauki. W formularzu biograficznym szczególny nacisk położono na tzw. „motywy interkulturowe”, które należy rozumieć jako potencjalną część kompleksu motywacyjnego, czerpiącą z szerzej rozumianych kulturowych, a nie tylko językowych, różnic pomiędzy kulturą rodzimą (kultura J1) a kulturą kraju języka docelowego (kultura J2). Istotną rolę w motywacji interkulturowej odgrywają: kulturowe „zaprogramowanie" uczącego się, jego własne środowisko socjokulturowe, kulturowa specyfika (początkowo) obcej kultury i jej postrzeganie przez uczącego

\footnotetext{
${ }^{1}$ I tak np. badani studenci germanistyki otrzymali następujący impuls: „Bitte berichten Sie über Ihre bisherigen Erfahrungen beim Lernen und Gebrauch von Fremdsprachen und dabei insbesondere über die damit verbundenen Motive (Warum lernen Sie Deutsch? Warum haben Sie Deutsch gelernt?) und Motivationen, Ängste und (Miss-) Erfolgserlebnisse. Berücksichtigen Sie dabei insbesondere die Fremdsprachen Englisch und Deutsch - ohne andere Fremdsprachen dabei zu vergessen. Schreiben Sie alles, was Sie wichtig finden. Vorgeschlagener Umfang: 1-3 Seiten.“ (Riemer 2005: 61)
} 
się (por. Mackiewicz, 2013: 161). Wzajemne oddziaływanie kultury J1 i kultury J2 (i uświadomienie sobie tej relacji przez uczącego się) jest tym samym fundamentalne dla motywacji interkulturowej. Tzw. świadomość kulturowa jawi się w tym kontekście jako niezbędny czynnik motywacji interkulturowej. Dla pełniejszego zrozumienia kulturowego komponentu motywacji istotne jest także ujęcie w badaniach empirycznych obrazu grupy etnicznej języka docelowego, jak i nastawienia do niej. Biografie sporządzone na potrzeby niniejszego badania poruszają także ten wątek, jednak z racji ograniczonego miejsca nie zostanie on w artykule uwzględniony.

Lista pytań badawczych została na potrzeby artykułu także ograniczona i obejmuje następujące kwestie:

- Czy i jak formuła biografii językowej pobudza refleksyjność polskich studentów uczących się języka niemieckiego?

- Jak dynamiczna jest motywacja w dłuższej perspektywie czasowej?

- Czy i ewentualnie jakie motywy interkulturowe odgrywają istotną rolę w poszczególnych fazach nauki języka niemieckiego?

- Jaką rolę odgrywa orientacja instrumentalna? (por. Gardner, 1985)

- Czy silniejsza motywacja interkulturowa wpływa pozytywnie na uzyskiwane wyniki?

Jak każde badanie jakościowe, biografie językowe nie służyły do określenia parametrów liczbowych. Pytania badawcze prowadzić miały do pogłębionej analizy motywacji uczących się języka niemieckiego w oparciu o mniejszą, niż w przypadku badań ilościowych, grupę badawczą. Badania ilościowe na dużej próbie (1009 osób) poprzedziły niniejsze badania jakościowe (por. częściowe wyniki badań ilościowych w: Mackiewicz, 2013), tym samym posłużono się $w$ przebiegu całego procesu empirycznego tzw. „Mixed Method Design“ (por. Brake, 2011: 47; Flick, 2011: 20). Kombinacja metod ilościowych i jakościowych, jako jeden z wariantów triangulacji (por. Kelle, 2008: 40), daje możliwość wielowymiarowego ujęcia problemu. W kontekście triangulacji mówi się o tzw. "słabym” i „silnym” programie (Flick, 2011: 22-23). Uwzględnienie biografii jako instrumentu badania jakościowego rozumieć tutaj należy jako „silny program”, ponieważ poprzez to badanie nie weryfikuje się wyników badań ilościowych, lecz poszerza możliwości poznawcze (ibidem: 23). Dzięki takiemu podejściu, nieuwzględnienie wyników badań ilościowych w niniejszym artykule nie wpływa negatywnie na możliwość odpowiedzi na powyżej postawione pytania badawcze. 


\subsection{Uczestnicy badania}

Badanie przeprowadzono w trakcie semestru letniego 2011/2012. W badaniu wzięło udział 73 studentów i studentek z pięciu polskich uczelni²:

1. Państwowa Wyższa Szkoła Zawodowa - Zamość $\left(P W S Z^{3}\right)-n=10$

2. Politechnika Śląska - Gliwice (PS) $-n=13$

3. Szkoła Główna Handlowa - Warszawa (SGH) - n=27

4. Uniwersytet im. Adama Mickiewicza - Poznań (UAM) $-n=15$

5. Wyższa Szkoła Bankowa w Poznaniu - Poznań (WSB) $-\mathrm{n}=8$

Badanymi, a więc „biografami”, byli studenci uczestniczący aktualnie w lektoratach języka niemieckiego i reprezentujący różne kierunki studiów: ekonomia, geografia, turystyka i rekreacja, kierunki techniczne, matematyka, stosunki międzynarodowe, zarządzanie, filologia angielska, administracja, logistyka.

Wśród badanych było 41 kobiet i 32 mężczyzn, których wiek wahał się w przedziale 19-25 lat (średnia wieku ok. 21,5 lat). Pierwszym językiem wszystkich badanych jest język polski. Dla 33 biografów pierwszym językiem obcym był język niemiecki, natomiast dla 40 - język angielski. Inne języki obce, których badani się uczyli, bądź nadal się uczą, to: hiszpański (3), rosyjski (3), francuski, włoski oraz szwedzki. Ponad połowa badanych (41) deklarowała znajomość języka niemieckiego na poziomie $A 2$, pozostałe poziomy to odpowiednio: A1 - 4, B1 - 8, B2 - 20.

\subsection{Narzędzie badawcze i przebieg badania}

Ryzyko małej kooperatywności badanych, a w skrajnych przypadkach nawet niechęć wobec metod ankietowych, dotyczy szczególnie badań jakościowych. Pewna gotowość do współpracy jest niezbędna, jeżeli jednak jest ona niewielka, to wydaje się, że otwarty format biografii i jej narracyjna forma, mogą działać dodatkowo demotywująco i skutkować nieprzemyślanymi i bardzo krótkimi odpowiedziami. Istotne dla badania kwestie mogą w ten sposób nie zostać uwzględnione. $Z$ tego powodu, do niniejszego badania wykorzystano ustrukturyzowaną biografię, która ma półotwartą formę i uwzględnia tym samym wszystkie istotne dla badania aspekty. Taki format

\footnotetext{
${ }^{2}$ Za pomoc w przeprowadzeniu badania bardzo dziękuję Agnieszce Szarzyńskiej (PWSZ Zamość), Gabrieli Szewioli (Politechnika Śląska), Sylwii Bochenek-Roik (SGH), oraz Ewie Stroik (UAM).

${ }^{3}$ Skróty nazw uczelni posłużą do kodowania wypowiedzi przytaczanych w dalszej części artykułu.
} 
gwarantuje z jednej strony uzyskanie danych jakościowych, z drugiej zaś, tok myślowy biografów jest do pewnego stopnia sterowany, tak, aby istotne dla badania kwestie nie zostały pominięte. Skrajnie ustrukturyzowaną formę wykazuje np. biografia językowa, którą uwzględniono w „Europejskim Portfolio Językowym” (CODN, 2005). Wysoki stopień ustrukturyzowania formatu zawartego w „Portfolio”, jak też uwzględnienie ilościowych instrumentów ankietowych (pytania wielokrotnego wyboru), ma na celu wspieranie samorefleksji ucznia i uzyskanie wieloaspektowego obrazu procesu uczenia się języka obcego. Nasz format jest w tym porównaniu bardziej otwarty. Zaproponowany tutaj format biografii językowej nie podaje, zgodnie z metodyką jakościową, gotowych odpowiedzi do wyboru, lecz zadaje biografom jedynie liczne pytania. Z „Portfolio” została zaadaptowana do naszych potrzeb wyłącznie rubryka „Moje doświadczenia” (ibidem: 16-18), dotycząca dotychczasowej nauki języków obcych i kontaktów z osobami obcojęzycznymi.

Impulsem do refleksji nad motywacją i nastawieniami do nauki języka niemieckiego był krótki wstęp do arkusza biograficznego:

Proszę spojrzeć wstecz na cały okres, w którym uczyliście się Państwo języka niemieckiego i skoncentrować się na trzech momentach: poczq̨tku Państwa nauki, jej środkowej fazie i na stanie obecnym. Proszę zwrócić uwagę na pytania pomocnicze!

Zasadnicza część arkusza obejmowała następujące punkty:

I. Dane osobowe

II. Podstawowe informacje - (1) nauka języków obcych; (2) Pana/Pani dotychczasowe kontakty z krajami niemieckojęzycznymi i/lub z Niemcami, Austriakami, Szwajcarami

III. Motywacja interkulturowa kiedyś i obecnie

1. Poczq̨ek

1.1. Decyzja podjęcia nauki j. niemieckiego

1.2. Motywacja

1.3. Motywowanie

1.4. Wiedza i doświadczenia kulturowe

1.5. Znaczenie kultury krajów niemieckojęzycznych i kompetencja interkulturowa

1.6. Obraz Niemiec

1.7. Pierwsze osiągnięcia/oceny

2. Faza środkowa

2.1. Motywacja

2.2. Motywowanie

2.3. Wiedza i doświadczenia kulturowe 
2.4. Znaczenie kultury krajów niemieckojęzycznych i kompetencja interkulturowa

2.5. Obraz Niemiec

2.6. Osiągnięcia/oceny

3. Stan obecny

3.1. Cele uczenia się j. niemieckiego

3.2. Motywacja - ogólne refleksje

3.3. Motywowanie

3.4. Świadomość kulturowa a motywacja i cele uczenia się

3.5. Wiedza kulturowa i kompetencja interkulturowa

3.6. Doświadczenia z krajami niemieckojęzycznymi i ich mieszkańcami a nauka j. niemieckiego

3.7. Komunikacja w j. niemieckim a motywacja

3.8. Obraz Niemiec

3.9. Nastawienie do Niemiec i Niemców a motywacja i umiejętności językowe

3.10. Osiągnięcia/oceny

Niniejsza struktura dotyczy całej biografii, która każdorazowo sporządzana była przez badanych studentów. Jak zaznaczono wcześniej, poniższa analiza obejmuje jedynie fragmenty odnoszące się do aspektów ściśle motywacyjnych, oraz ilustrujące znaczenie kultury krajów niemieckojęzycznych i miejsce kompetencji interkulturowej w procesie uczenia się JO.

\section{Analiza biografii}

Bezpośrednie doświadczenia z kulturą i społeczeństwem języka docelowego zadeklarowało 47 badanych. Przede wszystkim była to wymiana szkolna z Niemcami, rzadziej zaś wizyty u znajomych i krewnych w Niemczech. 26 studentów nie miało żadnych bezpośrednich kontaktów z osobami niemieckojęzycznymi.

\subsection{Motywacja w fazie początkowej}

Najczęściej decyzja związana była ściśle z obowiązkiem podjęcia nauki języka obcego w szkole podstawowej lub gimnazjum, preferencje dziecka były na tym etapie rzadko brane pod uwagę.

Ze względu na fakt, że języka niemieckiego zaczęłam się uczyć w piątej klasie szkoły podstawowej, decyzja o rozpoczęciu nauki nie była moją własną. Podjęli ją za mnie moi rodzice. Myślę, że wówczas nie byłam do końca świadoma celów uczenia się języka niemieckiego. (SGH/01) 
Biografia językowa jako przyczynek do refleksji nad motywacją do nauki...

W przypadku studenta, który naukę j. niemieckiego podjął świadomie dopiero w liceum, sytuacja wygląda zgoła inaczej:

Na początku nauki moja motywacja była bardzo sina i wkładałem bardzo dużo pracy w naukę. Motywacją była chęć zdawania matury z tego języka. Na początku silnie motywowały mnie ciekawe zajęcia oraz zaangażowanie nauczycieli. (PWSZ/01)

Sporadyczne pojawiają się refleksje wskazujące na bardziej wewnętrzne motywy podjęcia decyzji, nawet przez gimnazjalistów (przede wszystkim motyw komunikacyjny). I tak, w biografii PS/06 mowa jest o własnej decyzji, gdzie najważniejszym celem było spełnienie zawodowe i komunikacja z innymi w przyszłości. Co w tym przypadku istotne, motywy takie nie miały przełożenia na motywację, która w trakcie nauki bardzo szybko osłabła.

Biografowie wspominają także o słabej motywacji lub o braku motywacji. Język niemiecki jawi się wówczas jako „przymus” a biografowie, z dzisiejszej perspektywy, piszą o słabej refleksji nad przydatnością języka obcego u młodszych uczniów [Byłem za młody żeby zrozumieć istotę nauki języków obcych (PS/06)].

U starszych uczniów, rozpoczynających naukę np. w liceum, refleksja nad czynnikami demotywacyjnymi była bardziej świadoma:

Można powiedzieć, że gdy zaczynałem naukę w liceum, nie było żadnego czynnika, który szczególnie motywował mnie do nauki. Podręczniki to seria „Alles klar - poziom rozszerzony”, ale przez bardzo powolne tempo z jakim pracowaliśmy i przerwa w nauce, spowodowana brakiem lektorki przez 6 miesięcy, doszliśmy zaledwie do poziomu 2a. Zajęcia zwykle przebiegały schematycznie. Mianowicie, polegały na przerabianiu kolejnych rozdziałów. Dodatkowo nastawienie uczniów sprawiało, że miało się wrażenie, że jest to rzeczywiście język dodatkowy. W moim odczuciu język niemiecki w liceum jest traktowany po macoszemu, jako ten gorszy (być może wynika to też z gloryfikacji języka angielskiego jako tego międzynarodowego oraz po części z wciąż istniejących uprzedzeń Polaków wobec Niemców). Jest to niewątpliwie błąd, że młodzi Polacy faworyzują angielski, zamiast traktować te języki równorzędnie. (SGH/13)

Czynniki negatywnie wpływające na motywację w tej fazie to w świetle biografii: duża rotacja nauczycieli, zbyt schematyczne zajęcia, postrzeganie niemieckiego jako mniej wartościowego i nieprzydatnego języka, hegemonia (także mentalna) j. angielskiego wypierającego inne języki.

Szereg biografii potwierdza istotną rolę motywacji zewnętrznej w początkowej fazie szkolnej, gdzie to oceny są głównym czynnikiem motywacyjnym. 
Przede wszystkim świadectwo [motywowało mnie]. Zajęcia i nauczyciele na początku mojej drogi w kształceniu z języka nie byli zainteresowani przekazaniem wiedzy i zmotywowaniem. Przychodzili, „zrobili swoje”, zarobili swoje, a uczeń był na planie drugim, o ile nie na jeszcze dalszym. (WSB/05)

Motywowała jedynie możliwość uzyskania dobrej oceny, nie miało znaczenia rzeczywiste opanowanie języka. Nauka nie wymagała dużego wysiłku, gdyż materiał był mało obszerny, a podstawy języka łatwo przyswajalne. (SGH/24) Na początku nauki języka niemieckiego w szkole głównym czynnikiem motywującym były oceny z różnego rodzaju kartkówek, klasówek itp. Ze względu na fakt, że rozpoczęłam naukę będąc jeszcze dzieckiem, nie musiałam wkładać specjalnie dużo wysiłku w przyswajanie nowych treści (nauka odbywała się w znacznej mierze przez zabawę np. poprzez zapamiętywanie piosenek itd.). (SGH/01)

Motywacja zewnętrzna związana z ocenami mogła być jednak wsparta innymi motywami, np. motywem „rodzicielskim” czy „nauczycielskim”, jak w poniższych dwóch przykładach:

Na początku nauki motywacja była dość duża. Ważnymi czynnikami były: zaliczenie poszczególnych sprawdzianów z dobrym wynikiem, pochwały ze strony nauczyciela i innych, chęć zdobycia wiedzy. (PS/08)

Motywacja była duża. Chęć zdobycia dobrych stopni. Udowodnienia rodzicom, że potrafię. (PS/10)

W przypadku, gdy początek nauki j. niemieckiego przypadł na okres studiów, oceny stawały się mniej istotne, natomiast motywacja wewnętrzna wzmacniała się:

Nie było motywacji w postaci oceny liczonej do średniej, był to przedmiot dodatkowy, była automotywacja plus motywująca do nauki nauczycielka. (PS/04)

Duża motywacja początkowa wśród uczniów wynikała z przeżycia czegoś „nowego” i przez to atrakcyjnego. Motywy takie z samej swojej natury były bardzo nietrwałe a ogólna motywacja malała w związku z pojawieniem się czynników demotywujących:

Na początku motywacja była duża z powodu poznania nowego języka, lecz po dalszym kontynuowaniu nauki stopniowo opadała. (UAM/08)

Jak każdy uczeń początkowo byłem bardzo zainteresowany nauką nowego języka. Jednakże niewłaściwa motywacja ze strony nauczycieli (a właściwie jej brak), monotonne zajęcia, a może przede wszystkim brak perspektyw do zastosowania nauki w życiu, sprawiły, że zlekceważyłem ten język i nie włożyłem dostatecznego wysiłku w jego naukę. Teraz dopiero zauważam jak wielki 
Biografia językowa jako przyczynek do refleksji nad motywacją do nauki...

to był błąd i jak wiele mogłaby zmienić praca nad językiem od podstaw, przy odpowiedniej motywacji. (SGH/13)

Zarejestrowano także przypadki odwrotne: motywująca nowość języka zostaje z czasem zastąpiona innymi czynnikami motywującymi (np. oceny albo chęć wyróżnienia się wśród uczniów):

Uczyłem się chętnie. Przychodziło mi to łatwo. Początkowo miałem dużą motywację, w końcu uczyłem się czegoś innego niż angielskiego (podobnie rzecz się miała z łaciną). Poziom był podstawowy więc miałem dobre stopnie co motywowało mnie do dalszej nauki. Nie poświęcałem dużo czasu, na pewno więcej j angielskiemu, na którym miałem wyższy poziom i który zdawałem na maturze na poziomie rozszerzonym. (PS/11)

Byłam dzieckiem ciekawym świata i chętnym do nauki, naukę języka traktowałam jako zabawę. W gimnazjum niewiele osób uczyło się niemieckiego, głównie angielskiego, dlatego miałam ambicję, żeby się wyróżnić i być jak najlepsza. Spędzałam dużo czasu nad nauką niemieckiego, rzetelnie odrabiałam wszystkie prace domowe, chętnie uczestniczyłam w zajęciach, często uczyłam się dodatkowych słówek w domu. (SGH/12)

Generalny wniosek wynikający z analizy pierwszych części biografii językowej wskazuje na fakt, iż żaden biograf nie podkreśla kulturowych, interkulturowych, czy integracyjnych aspektów początkowej motywacji do nauki j. niemieckiego. Także refleksje w reakcji na pytanie o znaczenie kultury języka docelowego i/lub kompetencji interkulturowej $w$ tej fazie potwierdzają najczęściej dominację motywów instrumentalnych i mało znaczącą rolę motywów interkulturowych.

\subsection{Motywacja w fazie środkowej}

Stała motywacja w kolejnej fazie dotyczy przede wszystkim uczniów od początku słabo zmotywowanych, lub zmotywowanych wyłącznie ocenami:

Szczególnie motywowało mnie to, aby przechodzić z klasy do klasy. (UAM/06) 2-3 klasa liceum weźmy pod uwagę. Wątpię, że cokolwiek uległo zmianie. Materiał był z pewnością trochę trudniejszy ale nie na tyle żeby nie dało się 'ogarnąć', więc uważam że motywacja nie uległa zmianie. Możliwe że trochę entuzjazm opadł, gdyż poziom jak zaznaczam nie był wysoki, nauczyciel nie wymagał od nas cudów nie trzeba było się zbytnio przygotowywać żeby zaliczać wszystko. Myślę, że wchodził automatyzm 'byle zaliczyć ten niemiecki na 5 i mieć spokój'. (PS/11) 
Biografowie deklarujący większą motywację w tej fazie, wskazują przede wszystkim na wzrost znaczenia motywów pragmatycznych, np. komunikacyjnych i związanych z przyszłą pracą zawodową:

Szczególnie ważnym czynnikiem motywującym był szybki postęp w komunikowaniu się w języku niemieckim, na który ogromny wpływ miała lektorka z SGH. Motywujący był również wysoki poziom nauczania i ciągły kontakt z językiem, możliwość rozwoju. (SGH/14)

Ze względu na fakt, że podczas środkowej fazy mojej nauki języka niemieckiego byłam w dalszym ciągu uczniem, motywacją były dla mnie głównie oceny. Zmieniła się także moja świadomość, gdyż zdałam sobie sprawę, że nauka języka niemieckiego może przynieść profity w przyszłości. Z każdym rokiem wkładałam coraz więcej wysiłku w naukę języka obcego. (SGH/01)

Zacząłem myśleć praktyczniej- że język może mi się przydać nie tylko do czerwonego paska na świadectwie, ale też być może do przyszłej pracy, zacząłem też być w pewnym sensie dumny, że znam ten język dosyć dobrze. Zacząłem również myśleć o maturze z tego języka, i to najpewniej właśnie motywowało mnie do nauki j. niemieckiego. (UAM/11)

Niektóre biografie, które także wskazują na motywację rosnącą w tej fazie, nie wysuwają motywów pragmatycznych na pierwszy plan, lecz podkreślają czynniki ambicjonalne:

Trafiłem do znacznie lepszej szkoły i do nowego miasta (Szczecin), więc samo to było ważną motywacją do nauki właściwie wszystkiego, pomogło na pewno to, że okazałem się lepszy z niemieckiego niż moi przeciętni koledzy ze szkoły (SGH/10) Środkowa faza nauki przypada w moim przypadku na czas liceum, kiedy świadomie wybrałam klasę z obowiązkowym językiem niemieckim i zdecydowałam się przyłożyć do jego nauki. Włożyłam dużo wysiłku w nadrobienie zaległości z gimnazjum, kiedy zaniedbałam naukę niemieckiego. Moja motywacja zdecydowanie wzrosła. (SGH/11)

Motywacją w tym okresie (uważam go za 1 rok studiów) kiedy trafiłem na uczelni na wymagającą lektorkę, aczkolwiek też bardzo dobrą motywatorkę. Niebywały wzrost poziomu językowego (właściwie przepaść między liceum a studiami) przełożyły się na motywację, jako że zawsze lubiłem wyzwania. (SGH/13)

Motywacja malejąca w środkowej fazie związana jest m.in. z konkurencyjną pozycją zajęć języka angielskiego:

Moja motywacja do nauki się zmniejszyła w porównaniu do fazy początkowej mojej nauki. W naukę wkładałam mniej wysiłku, gdyż więcej czasu spędzałam na nauce języka angielskiego. (PS/08) 
Biografia językowa jako przyczynek do refleksji nad motywacją do nauki...

Uczyłam się mniej pilnie, bardziej fascynował mnie angielski - był ładniejszy i łatwiejszy. Choć dzięki niemieckiemu mogłam się wyróżnić. (SGH/12)

Inną przyczyną malejącej motywacji są, paradoksalnie, początkowe sukcesy prowadzące do „spoczęcia na laurach”. Kolejny przykład ilustruje taki właśnie przypadek, choć jednocześnie wskazuje na możliwość przełamania stagnacji motywacyjnej:

Na tym etapie już się wydawało, że się dużo wie i przychodzi takie rozleniwienie. Tak było w moim przypadku. Pierwsze zdania które wypowiadałem budziło zadowolenie wokół w rodzinie. No i w tym momencie trochę mniej się przykładałem ale pokonałem ten kryzys i już lepiej mi idzie. (WSB/03)

Szczególne miejsce, zgodnie z oczekiwaniami, zajmuje w analizowanych biografiach motywująca lub demotywująca rola nauczyciela i materiałów dydaktycznych. Te dwa istotne czynniki jawią się w refleksjach biografów jako raczej demotywujące:

Nowy nauczyciel nie potrafił wpłynąć na mnie tak bym zwiększyła motywację do nauki. Moje oceny się pogorszyły. (PS/08)

Motywował jedynie wyścig o dobre stopnie i średnią. Same zajęcia, nauczyciel, podręczniki działały demotywująco. Rodzice nie wpływali na motywację. (SGH/24)

Motywowała mnie własna wiedza i rozsądek. Nauczyciele i podręczniki to główne podmioty demotywujące. (WSB/05)

Z drugiej strony pojawia się jednak szereg wspomnień wskazujących na motywującą rolę nauczyciela i materiałów dydaktycznych:

Osobą, która motywowała mnie w największym stopniu podczas tej fazy była moja nauczycielka niemieckiego z liceum, która wkładała ogromną energię i zaangażowanie w nauczanie języka niemieckiego. Była bardzo wymagająca, ale doskonale zorganizowana. Ponadto stosowała interesujący zestaw podręczników i pomocy naukowych. (SGH/11)

Tutaj motywowały mnie każde zajęcia (bardzo wymagające), lektorka, która kładła duży nacisk na pokazanie nam jak ważny jest język niemiecki, jak wiele płynie korzyści z jego nauki. Podręcznik to „Blickpunkt Wirtschaft” oraz różne filmy o treści ekonomicznej, wiadomości po niemiecku itd. To sprawiło, że zacząłem więcej uwagi poświęcać niemieckiemu. (SGH/13)

Motywował mnie dostęp do ekonomicznej prasy niemieckiej, lektorki, multimedia. (SGH/14)

Miły nauczyciel, chęć uzyskiwania dobrych ocen, rozumienia ze słuchu, oglądanie filmów niemieckich. (SGH/26) 
Każdy kontakt z każdym innym nauczycielem języka niemieckiego czy to w podstawówce czy gimnazjum/liceum stawiał nowe zadania do wykonania, nowe podręczniki, oferujące nowe słownictwo itp. (UAM/05)

Podobnie jak na początku, także w tej fazie (inter)kulturowe czynniki raczej nie wspierają motywacji. Tylko jedna biografia wskazuje na związek pomiędzy zainteresowaniami kulturowymi a motywacją. Biografem jest tutaj student, który jeszcze jako nastoletni uczeń w pełni uświadomił sobie niemieckie dziedzictwo swojego rodzinnego miasta:

Szkoła była pierwszym punktem motywacji, ale powoli pojawiał się następny. Historia mojego regionu, miasta była historią Niemców i rosła we mnie chęć jej poznania w źródłach niemieckich. Nawet w domu babci czekała skrzynia odnalezionych, porzuconych w 1945 r. dokumentów, które czekały na tłumacza. (SGH/10)

Motywacja nie jest wspierana przez motywy interkulturowe, a wg typowej refleksji wielu studentów, nie przywiązywali oni wagi „do takiego zagadnienia" (PS/11). U niektórych biografów aspekty kulturowe zyskują wprawdzie na znaczeniu, ale tylko w ograniczonym zakresie:

Przede wszystkim miała znaczenie znajomość obyczajów niemieckich. (SGH/12) W trakcie nauki niemieckiego zaciekawiłam się kulturą niemiecką i wzrosło jej znaczenie. (SGH/14)

Same zagadnienia na temat kultury krajów niemieckojęzycznych nabrały znaczenia, wydawały się być interesujące, ale nie na tyle, aby samemu zgłębiać ich tajniki. Traktowało się je jako ciekawszą część podstawy programowej, która wtedy nie wydawała się mieć praktycznego zastosowania. (SGH/24)

Zdobycie tej wiedzy i umiejętności były zdecydowanie ważniejsze niż na początku. Mogłem porównać kulturę niemiecką i polską. (WSB/06)

\subsection{Motywacja - stan obecny}

Analizując refleksje na temat aktualnej motywacji i bieżącej nauki j. niemieckiego w ramach lektoratów, zauważa się generalnie większą świadomość celów uczenia się (lub ich braku) i bardziej świadomą refleksję nad własną motywacją lub demotywacją.

Brak celów i całkowita demotywacja manifestowane są np. w przypadku, gdy inne, bardziej istotne z perspektywy studenta wyzwania, dewaluują zasadność uczenia się j. niemieckiego: 
Biografia językowa jako przyczynek do refleksji nad motywacją do nauki...

Brak celów. Kompletny brak czasu związany z pracą mgr. Język niemiecki męczarnią. Obecnie nie mam motywacji. Nic mnie nie motywuje. (PS/06)

W kolejnym przykładzie cele nadal są klarowne a motywacja wewnętrzna, lecz także tutaj lektorat w ramach studiów nie jest priorytetem:

Moim celem jest płynna, swobodna komunikacja z mieszkańcami krajów niemieckojęzycznych. Motywacja nie jest już taka silna z powodu natłoku nauki. Mimo to, uczę się z wewnętrznej potrzeby, staram się na tyle, na ile mogę. (PWSZ/01)

Inna biografia wskazuje na nieco mniejszą motywację ze względu na rozczarowujące efekty dużego wysiłku włożonego w naukę języka. W poniższym przykładzie wyraźny jest negatywny wpływ słabszych niż oczekiwano efektów, które kontrastują z deklarowaną wewnętrzną motywacją i sporym wysiłkiem włożonym w naukę j. niemieckiego. Nadal obecne motywy wewnętrzne oraz motywowanie ze strony lektorów nie dopuszczają jednak tendencji do całkowitej demotywacji.

Celem jest nauczyć się języka niemieckiego jak najlepiej i posługiwać się nim bez problemów. Najważniejsze jest aby mówić bezbłędnie po niemiecku. Uczę się oczywiście z wewnętrznej potrzeby ale oczywiście miło jest zawsze być nagrodzonym. Przygotowania na zajęcia pochłaniają sporo czasu i są dość intensywne. Aktualna motywacja jest ciut mniejsza ze względów na małe przełożenie nakładu pracy na ogólne umiejętności. Motywują mnie perspektywy w przyszłości, lektorki. (SGH/07)

U generalnie mocno zmotywowanych studentów, pewien spadek poziomu motywacji w porównaniu z wcześniejszą fazą związany jest z obiektywnymi czynnikami zmniejszającymi intensywność motywacji, przede wszystkim z hierarchią obowiązków i zadań na uczelni.

Bezpośrednim celem jest w chwili obecnej pomyślne zdanie egzaminu. W fazie długofalowej, wykorzystanie w życiu zawodowym i prywatnym (np. za cel stawiam sobie oglądanie filmów w języku niemieckim). Motywacja silna, aczkolwiek odrobinę słabsza niż w środkowej fazie. Uczę się z wewnętrznej potrzeby, ale niestety z braku czasu nie poświęcam nauce tyle czasu, co kiedyś (kiedy to, np. regularnie powtarzałam słówka za pośrednictwem programu komputerowego). (SGH/15)

Szereg biografów, którzy stwierdzają w ostatnim czasie motywację rosnącą, wskazuje na coraz ważniejsze cele i motywy komunikacyjne: 
Cel: aby nauczyć się swobodnie komunikować w języku niemieckim, przełamać pewną barierę związaną z mówieniem. Najważniejsza jest dla mnie zdolność łatwego wypowiadania się. Moja motywacja jest obecnie dosyć duża. Języka niemieckiego uczę się z własnej potrzeby. Uczęszczam na dobrowolne zajęcia z tego języka na studiach. Moje starania są intensywne, gdyż zdaje sobie sprawę, że znajomość niemieckiego może być w przyszłości atutem na rynku pracy. (SGH/01)

Obecnie nauka j. niemieckiego jest dla mnie ważna w kontekście przyszłego poszukiwania pracy, dobra jego znajomość może mi w tym pomóc. Myślę, że najważniejsza dla mnie jest przede wszystkim komunikatywność w tym języku oraz znajomość jak największego zasobu słownictwa. Obecnie moja motywacja jest dość duża, staram się korzystać z każdej okazji aby poprawić swoją znajomość języka. Oceny są ważnym czynnikiem dla mnie, ponieważ pokazują w pewnym stopniu poziom opanowania materiału podczas zajęć. Ważniejsze jest jednak aby potrafić swobodnie porozumiewać się w języku, nie opierając się tylko na teorii. Najbardziej motywuje mnie to, że bez znajomości języków obcych trudno jest obecnie o znalezienie dobrej pracy i perspektyw na przyszłość. (WSB/06)

W kilku innych biografiach wyraźny jest niewielki wpływ ocen na aktualną motywację, podkreślana jest przy tym silna motywacja wewnętrzna. Jednocześnie, przede wszystkim w drugim poniżej cytowanym fragmencie, symptomatyczny jest wysoki stopień refleksyjności biografa.

Dalej jest to możliwość porozumiewania się w języku niemieckim. Oprócz tego uczę się niemieckiego, aby wykorzystywać go w życiu zawodowym. System uczenia się języka niemieckiego na mojej uczelni skutecznie zniechęca do nauki. Uczę się zdecydowanie dla siebie, aby poszerzyć własną wiedzę. Ocena nie jest czynnikiem motywującym. Starania są niestety coraz mniejsze. (SGH/18) Motywację obecnie mam dużą. Myślę zresztą, że z czasem każdy młody człowiek zauważa, że „Człowiek uczy się nie dla szkoły, lecz dla siebie”, co w przypadku języków jest w 100\% prawdą. Myślę, że już bardziej niż oceny na moją motywację wpływa też nazywana w psychologii „chęć odwzajemnienia poświęcenia i zaufania”. Kiedy nauczyciele traktują uczniów właściwie (dbają o ich motywację, czasem chwalą, czasem wskazują nad czym popracować, w trudnych momentach, których w trakcie długoletniej nauki języka nie brakuje, pokazują, jak wiele już się przeszło i jak dobrze już władamy językiem), z czasem uczniowie starają się spłacić ten dług swoją pracą i zaangażowaniem. Być może gdybym spotkał w liceum nauczycieli takich jak tu, byłbym teraz dwa razy lepszy, jeśli chodzi o stopień zaawansowania. (SGH/13)

W teorii motywacji poczesną rolę zajmuje tzw. „motyw niepowodzenia" (por. Rudolph, 2007: 96; Weiner, 1994: 154). W jednej z biografii obawy związane z doświadczeniem swoistego „wstydu” spowodowanego ewentualną porażką, są głównym motorem napędzającym zaangażowanie się 
Biografia językowa jako przyczynek do refleksji nad motywacją do nauki...

w naukę j. niemieckiego. „Tendencja do uniknięcia niepowodzenia” (Rudolph, 2007: 94) jest w następującym przykładzie aż nadto widoczna:

Celem jest chęć przypomnienia, zapomnianego już przez mnie języka i ew. podwyższenie poziomu na którym byłem w liceum. Chęć zrozumienia chociażby w piśmie niemieckiego w stopniu podstawowym, żebym wiedział chociaż o co chodzi. Motywuje raczej chęć nieskompromitowania się na całej linii na tle grupy, która jest na dużo, dużo wyższym poziomie niż ja. Mimo tego, iż wiem że nie mam szans dogonić ich poziomu. Perspektywa na przyszłość też po części, lecz motywacja motywacją a wychodzi co innego. (PS/11)

Biografie potwierdzają zarówno możliwość istnienia, jak i braku świadomości kulturowej uczących się j. niemieckiego, przy czym jedno i drugie nie musi wpływać na motywację. Szereg przykładów potwierdza natomiast, iż deklarowana świadomość kulturowa może wzmacniać motywację.

Studenci, którzy nie dostrzegają powiązań kulturowych i językowych nie widzą także, wg poniższych refleksji, związku pomiędzy kulturowym uczeniem się a motywacją do nauki języka niemieckiego:

Uważam, że kulturowe uczenie nie wspiera nauki. (UAM/07)

Raczej nie mam większej świadomości powiązań językowych i kulturowych. Kulturowe uczenie się jest teraz dla mnie minimalnie ważniejsze niż kiedyś, choć wciąż mało ważne. Raczej nie wspiera ono nauki języka. (UAM/09)

Na pewno wiem więcej o kulturze Niemiec niż miało to miejsce w liceum. Wiedzę tę czerpię jedynie z zajęć języka niemieckiego, na których pani prowadząca często opowiada o tym kraju. Jednakże nie mogę powiedzieć, że wywarło to na mnie jakiś wpływ, traktuje to raczej jako ciekawostkę. (PS/11)

Z kolei część badanych deklarujących świadomość kulturową, nie widzi jej wpływu na ogólną motywację do uczenia się j. niemieckiego. U innych natomiast, w ich subiektywnej opinii, rosnąca świadomość kulturowa wpływa pozytywnie na motywację. We fragmencie przytoczonym poniżej zwraca także uwagę szczególnie wysoki poziom refleksyjności:

Dziś śmiało mogę powiedzieć, że mam taką świadomość. Mogę również stwierdzić, że zajęcia mają na nią duży wpływ, co z kolei przekłada się na ogólną motywację do języków. Na moją motywację duży wpływ ma świadomość, że w niedalekiej przyszłości będę się nim (być może) regularnie posługiwał. To kulturowe uczenie jest bardzo ciekawe i zabawne. Zabawne jest to jak bardzo, mimo niewielkiej odległości), różnią się zwyczaje Niemców. Oczywiście jest to w pewnym stopniu motywatorem. Jednak jak już wspominałem, najważniejsi są nauczyciele i własna motywacja. Nauczyciele muszą 
„zarazić” ucznia językiem i pokazać, że: „Die Grenzen meiner Sprache bedeuten die Grenzen meiner Welt" (cyt. Wittgenstein). Większą świadomość kulturową można przypisać lekcjom jak również jest związana z samodzielnym śledzeniem prasy niemieckiej na bieżąco. Świadomość ta na pewno zwiększa motywację i kulturowe uczenie wspiera naukę j. niemieckiego. (SGH/14)

\section{Wnioski}

Nawiązując do pytań badawczych wyłącznie w odniesieniu do biografii językowych jako instrumentu badań jakościowych, należy sformułować następujące podstawowe wnioski:

- Sporządzenie biografii wyzwoliło u wielu studentów silną refleksyjność na temat dotychczasowej nauki j. niemieckiego i jej uwarunkowań wewnętrznych i zewnętrznych.

- Tworzenie biografii skłoniło badanych do (ewentualnie retrospektywnych) przemyśleń nad swoimi motywami, nastawieniami czy priorytetami w różnych fazach nauki j. niemieckiego. Te swoiste metarefleksje biografów świadczą o rosnącej z wiekiem refleksyjności dotyczącej tychże aspektów uczenia się języków obcych. Wyraźne jest wskazanie na raczej bezrefleksyjne uczenie się j. niemieckiego w okresie szkolnym, szczególnie w szkole podstawowej.

- Biografie potwierdzają u wielu badanych dynamiczny charakter motywacji w dłuższej perspektywie - kierunki zmian, ich intensywność i uwarunkowania mają charakter bardzo indywidualny.

Badania jakościowe nie pozwalają z reguły na zbyt uogólniające wnioski, mają one na celu przede wszystkim eksplorowanie problemu i pozwalają naświetlić go z wielu, czasem nieoczekiwanych stron. Analiza biografii w zestawieniu z wynikami szeroko zakrojonych badań ilościowych (Mackiewicz, 2013) pozwala jednak na pewną generalizację. Należy więc stwierdzić, że motywy interkulturowe nie odgrywają większej roli u polskich studentów uczących się j. niemieckiego. W ich przypadku przeważają motywy instrumentalne. Jednocześnie nie można jednoznacznie stwierdzić, iż studenci silniej zmotywowani interkulturowo osiągają lepsze wyniki, choć można w tej grupie mówić o większej satysfakcji z nauki j. niemieckiego.

\section{BIBLIOGRAFIA}

Brake, A. 2011. „Kombinieren, mixen, verbinden? Integration als konstitutives Element methodentriangulierender Zugänge" (w:) Methodentriangulation in der 
Biografia językowa jako przyczynek do refleksji nad motywacją do nauki...

qualitativen Bildungsforschung (red. J. Ecarius, I. Miethe). Opladen: Verlag Barbara Budrich: 41-63.

CODN 2005. Europejskie Portfolio Językowe dla uczniów szkół ponadgimnazjalnych i studentów. Warszawa: CODN.

Dörnyei, Z., Ottó, I. 1998. „Motivation in action: A process model of L2 motivation”. Working Papers in Applied Linguistics 4: 43-69.

Edmondson, W. J. 1996. „Was Lerner über ihr Fremdsprachenlernen berichten” (w:) Wie lernt man Sprachen - wie lehrt man Sprachen? Zwanzig Jahre Sprachlehrforschung am Zentralen Fremdspracheninstitut der Universität Hamburg (red. J. House). Hamburg: Zentrales Fremdspracheninstitut: 68-82.

Edmondson, W. J. 1997. „Sprachlernbewußtheit und Motivation beim Fremdsprachenlernen". Fremdsprachen Lehren und Lernen (FLuL) 26: 88-110.

Edmondson, W. J. 2000. „Grammatik und Kommunikation bei Auslandsaufenthalten” (w:) Sprachlehrforschung im Wandel. Beiträge zur Erforschung des Lehrens und Lernens von Fremdsprachen. Festschrift für Karl-Richard Bausch zum 60. Geburtstag (red. B. Helbig, K. Kleppin, F.G. Königs). Tübingen: Stauffenburg: 363-382.

Flick, U. 2011. „Zum Stand der Diskussion - Aktualität, Ansätze und Umsetzungen der Triangulation" (w:) Methodentriangulation in der qualitativen Bildungsforschung (red. J. Ecarius, I. Miethe). Opladen: Verlag Barbara Budrich: 19-39.

Franceschini, R. 2002. „Sprachbiographien: Erzählungen über Mehrsprachigkeit und deren Erkenntnisinteresse für die Spracherwerbsforschung und die Neurobiologie der Mehrsprachigkeit". Bulletin VALS-ASLA 76: 19-33.

Fuhs, B. 2007. Qualitative Methoden in der Erziehungswissenschaft. Darmstadt: WBG.

Gardner, R. C. 1985. Social Psychology and Second Language Learning. The Role of Attitudes and Motivation. London: Edward Arnold.

Gardner, R. C., Lambert, W. E. 1972. Attitudes and Motivation in Second-Language Learning. Rowley, MA: Newbury House Publishers.

Kelle, U. 2008. Die Integration qualitativer und quantitativer Methoden in der empirischen Sozialforschung. Theoretische Grundlagen und methodologische Konzepte. Wiesbaden: VS Verlag für Sozialwissenschaften.

Mackiewicz, M. 2013. „Fremdbilder und Einstellungen vs. Motivation zum Fremdsprachen- und Kulturlernen. Zur interkulturellen Motivation der polnischen DaFLernenden" (w:) Wissenschaftsmobilität und interkulturelle Kommunikation im deutsch-polnisch-tschechischen akademischen Kontext (red. A. Moosmüller, I. Waibel). Marburg: Tectum Verlag: 158-177.

Pawlak, M. 2012. „The dynamic nature of motivation in language learning: A classroom perspective". Studies in Second Language Learning and Teaching 2(2): 249-278.

Riemer, C. 2003. „Englisch war für mich nur ein Teil meines Stundenplans - Motivation zum Englischlernen in Zeiten der Globalisierung" (w:) Übersetzen, Interkulturelle Kommunikation, Spracherwerb und Sprachvermittlung - das Leben mit mehreren Sprachen. Festschrift für Juliane House zum 60. Geburtstag. Zeitschrift für Interkulturellen Fremdsprachenunterricht (red. N. Baumgarten, C. Böttger, M. Motz, J. Probst) 8(2/3): 72-96, http://zif.spz.tu-darmstadt.de/ jg-08-2-3/beitrag/Riemer1.htm DW 16.11.2012. 
Riemer, C. 2004. „Zur Relevanz qualitativer Daten in der neueren L2Motivationsforschung" (w:) Emotion und Kognition im Fremdsprachenunterricht (red. W. Börner, K. Vogel). Tübingen: Gunter Narr Verlag: 35-65.

Riemer, C. 2005. „L2-Motivationsforschung und Deutsch als Fremdsprache (mit exemplarischen Länderanalysen)" (w:) Sprache lehren - Sprache lernen (red. A. Wolff, C. Riemer, F. Neubauer). Regensburg: Fachverband Deutsch als Fremdsprache: 51-72.

Riemer, C. 2006. „DaF-Lernende - alles Exoten? Motivationsforschung und Deutsch als Fremdsprache" (w:) Innovationen - neue Wege im Deutschunterricht (red. H.-J. Krumm, P. Portmann-Tselikas). Innsbruck: Studienverlag: 43-58.

Riemer, C. 2010. „Erste Schritte empirischer Forschung: Themenfindung, Forschungsplanung, forschungsmethodische Entscheidungen" (w:) DaF integriert: Literatur - Medien - Ausbildung. Tagungsband der 36. Jahrestagung des Fachverbandes Deutsch als Fremdsprache 2008 (red. C. Chlosta, M. Jung). Göttingen: Universitätsverlag: 423-434.

Rudolph, U. 2007. Motivationspsychologie. Workbook Weinheim/Basel: Beltz.

Tophinke, D. 2002. „Lebensgeschichte und Sprache. Zum Konzept der Sprachbiografie aus linguistischer Sicht". Bulletin VALS-ASLA 76: 1-14.

Weiner, B. 1994. Motivationspsychologie. Weinheim: Beltz. 